\title{
Multivariate analysis of nutritional parameters required for the submerged cultivation of three coprinaceous fungi for biosurfactant production
}

\section{Análise multivariada dos parâmetros nutricionais necessários ao cultivo submerso de três fungos coprináceos para produção de biossurfactante}

\author{
Roberta Castro Martins ${ }^{1}$ (D), Claudia Eugênia Castro Bravo² (iD), Leonardo de Figueiredo Vilela ${ }^{3}$ (D), \\ Lívia Martinez Abreu Soares Costa1 ${ }^{10}$, Eustáquio Souza Dias ${ }^{1 *}$ (i)
}

\author{
${ }^{1}$ Universidade Federal de Lavras/UFLA, Departamento de Biologia/DBI, Lavras, MG, Brasil \\ ¿Universidade Tecnológica Federal do Paraná/ UTFPR-FB, Departamento Acadêmico de Química e Biologia, Francisco Beltrão, PR, Brasil \\ ${ }^{3}$ Suprema, Faculdade de Ciências Médicas de Três Rios/FCM/TR, Três Rios, RJ, Brasil \\ *Corresponding author: esdias@ufla.br \\ Received in August 18, 2020 and approved in January 21, 2021
}

\begin{abstract}
Biosurfactants are natural hydrocarbon surfactant compounds that decrease surface tension and have a high emulsifying capacity. Biosurfactants are produced through microbial metabolic processes and have several advantages over chemical surfactants, including low toxicity and high biodegradability. Bioremediation offers the possibility of eliminating or transforming various contaminant compounds present in soil and water. Fungi are effective transforming agents due to their ability to degrade a diverse variety of organic substances. Thus, considering the potential of fungi to produce biosurfactants and the importance of these compounds for various industrial processes, the objective of this work was to verify the effects and interactions of different concentrations of various nutrients on biosurfactant production in three coprinaceous fungi isolates. These isolates were obtained from spent mushroom substrate (SMS) produced during the edible mushroom growth process. All three fungal isolates, termed FS-4.1, FS-4.2, and FS-4.3, were potential sources for biosurfactant production, as evidenced by the emulsifier index of the fermentation medium. However, biosurfactant production was maximum in isolate FS-4.1, yielding an emulsifier index of $73.45 \%$. To optimize the FS-4.1 biosurfactant production process, corn oil, glycerol, and yeast extract must be absent from the fermentation medium (to minimize negative effects on the process) and increase the amounts of glucose and soy oil.
\end{abstract}

Index terms: Biological surfactant; emulsifier index; Coprinus.

\section{RESUMO}

Biosurfactantes, são emulsificantes naturais de hidrocarbonetos que diminuem a tensão superficial e têm alta capacidade de emulsionamento. Os biossurfactantes são produzidos pelo metabolismo de microrganismos e apresentam vantagens sobre o uso de surfactantes químicos, principalmente por sua baixa toxicidade e alta biodegradabilidade. A biorremediação é uma opção para a transformação de vários compostos contaminantes no solo e na água, sendo que os fungos são agentes transformadores eficazes, dada a sua capacidade de degradar uma ampla diversidade de substâncias orgânicas. Assim, considerando o potencial dos fungos na produção de biossurfactantes e a importância desses compostos para vários processos industriais, o objetivo deste trabalho foi verificar o efeito e as interações das concentrações de diferentes nutrientes na produção de biossurfactantes, utilizando três fungos coprináceos isolados do substrato pós-cultivo de cogumelos (spent mushroom substrate - SMS) resultante do processo de cultivo de cogumelos comestíveis. Os isolados fúngicos filamentosos codificados FS-4.1, FS-4.2 e FS-4.3 demonstraram potencial de produção de biossurfactantes, evidenciado pelo índice emulsificante no meio de fermentação. No entanto a produção biosurfactante foi máxima no isolado FS-4.1, produzindo um índice de emulsificante de $73,45 \%$. Para otimizar o processo de produção biosurfactante FS-4.1 o óleo de milho, o glicerol e o extrato de levedura devem estar ausentes do meio de fermentação (para eliminar os efeitos negativos no processo) e aumentar as quantidades de glicose e óleo de soja.

Termos para indexação: Surfactante biológico; índice emulsificante; Coprinus. 


\section{INTRODUCTION}

Biosurfactants are biopolymers of microbial origin (bacteria, yeasts, and fungi) that are composed of hydrophobic and hydrophilic moieties. Biosurfactants are a viable alternative to synthetic surfactants, characterized by low toxicity and high biodegradability, and are amenable to low-cost production using agro-industrial raw materials (Mukherjee; Das; Sen, 2006). Biosurfactants comprise a large group of chemical compounds, including glycolipids, lipopeptides, phospholipids, lipoproteins, and lipidpolysaccharide complexes (Van Hamme; Singh; Ward, 2006). Their potential applications include their use as emulsifiers, conditioners, cosmetics, and in food industries (Asgher et al., 2020). Previous studies have mostly described the production of biosurfactants from bacteria (Joshi et al., 2008; Zhao et al., 2017; Rani; Weadge; Jabaji, 2020). In contrast, the production of fungal biosurfactants has rarely been described in the literature, although some studies have reported on the ability of specific fungi, mainly ascomycetous yeasts and filamentous fungi, to produce these compounds (Sen et al., 2017; Sanches et al., 2018; Da Silva et al., 2019). Although biosurfactants are produced by all fungal species, previous studies on biosurfactant production from basidiomycetes are scarce.

Biosurfactants play an important role in the bioremediation of impacted environments, as they facilitate the emulsification and solubilization of hydrophobic compounds, making them available for subsequent biodegradation (Karlapudi et al., 2018). As a consequence of this process, microorganisms can utilize the chemical contaminants in the soil as a source of energy and, through oxidation-reduction reactions, metabolize these compounds. Biosurfactants are synthesized by bacteria and fungi using a variety of substrates, including sugars, glycerol, oils, hydrocarbons, and alternative substrates such as agro-industrial residues (Cooper; Goldenberg, 1987; Khopade et al., 2012; Das; Kumar, 2019).

Within the group of xenobiotic-degrading fungi, lignolytic fungi that act on lignin degradation are exceptional, as they can tolerate pollutants at concentrations toxic to other organisms (Van den Brink et al., 1998). The enzymatic systems of lignolytic fungi is composed of lignin peroxidase, laccase, and manganesedependent peroxidase, which catalyze the metabolization of lignin-like structures, including polycyclic aromatic hydrocarbons (PAHs) and phenols (Eggen; Sasek, 2002). Although the utilization of fungi for the removal of pollutants has been studied for the last 30 years, it has gained prominence in recent years. In recent decades, there has been a steady increase in research concerning the production of biosurfactants by filamentous fungi (Soares et al., 2011; Pereira; Duvoisin; Albuquerque, 2017).

Following demonstration of their usefulness for biodegradation and their use of enzymatic systems that biochemically transform organic compounds into a nutrient and energy source, fungi are considered an attractive and promising group of microorganisms for use in the degradation of contaminants and for the recovery of degraded areas. Spent mushroom substrate (SMS) refers to the biomass waste generated from mushroom production (Lin; Ge; Li, 2014). SMS contains a rich microbiota and composition that can be used in a variety of applications, including bioremediation agents, feed supplements, substrates in agriculture, energy, and wastewater treatment (Rinker, 2017; Moraes et al., 2020).

Any study on the biosurfactant production should investigate the factors that influence microbial growth, including the optimum environmental and nutritional conditions necessary for growth (Varjani; Upasani, 2017). Data concerning factors that affect growth, such as requirement for carbon, nitrogen, phosphorus, iron, manganese, and magnesium, as well as $\mathrm{pH}$, temperature, agitation, oxygen availability, and process conduction, are of significant value in any study on production efficiency. Depending on the culture medium composition, microorganisms may produce biosurfactants with variable properties, especially when there are changes in the carbon source (Banat, 1995; Fontes et al., 2008).

Choice of carbon and nitrogen sources based on the classic optimization method (changing an independent variable while keeping others fixed) is both timeconsuming and expensive, especially in the case of a large number of variables. In addition, observing the effects of variables and their interactions is important to understand the processes undergoing in a specified system (PereiraFilho; Poppi; Arruda, 2002). The limitations of the singlefactor optimization process can be overcome through the use of multifactor statistical experimental designs, such as the factorial and surface response experimental design (Joshi et al., 2008). According to Peralta-Zamora, Moraes and Nagata (2005), factorial experimental planning allows us to simultaneously evaluate the effect of a large number of variables from a small number of experimental trials.

In this context, the objective of the present study was to verify the effects and interactions of different concentrations of nutrients on biosurfactant production and to study the ideal conditions for biosurfactant production by coprinaceous basidiomycetes isolated from SMS coded as FS-4.1, FS-4.2, and FS-4.3. 


\section{MATERIAL AND METHODS}

\section{Selection of fungal producers of biosurfactants}

Basidiomycetous fungi isolated from SMS were maintained in test tubes containing potato dextrose agar (PDA) at $4^{\circ} \mathrm{C}$. To select the biosurfactant-producing fungi, we analyzed the emulsification index of the culture filtrate. Three isolates (FS-4.1, FS-4.2, and FS-4.3) showed a high emulsification index. These three isolates were identified as Coprinus sp. by their characteristic macroscopic and microscopic features, as described by Largent, Suntz and Hadley (1986) and Putzke and Putzke (2017).

\section{Experimental design}

The fractional factorial design $2^{(6-2)}$ was obtained using the Statistica 8.0 computer program. The fractional factorial design was used to reduce the number of experiments. Based on the systematic sequencing of factorial experiments, it was possible to statistically test the significance of the factors' effects, and develop empirical models that facilitate predicting the effects of specific combinations of factors on the system response variables, according to the testing interval taken into consideration (Montgomery, 1991).

Emulsifying activity was considered as the dependent variable, while soybean oil (X1), corn oil (X2), glycerol (X3), glucose (X4), ammonium sulfate (X5), and yeast extract (X6) were the independent variables studied in the factorial design $2^{(6-2)}$ as described in Table 1.

\section{Inoculum preparation and inoculation}

Inoculum were prepared by growing the fungal isolates FS-4.1, FS-4.2, and FS-4.3 in potato dextrose broth supplemented with yeast extract (PDYE) and incubated at $25{ }^{\circ} \mathrm{C}$ for $48 \mathrm{~h}$ while shaking at $200 \mathrm{rpm}$. Subsequently, $1 \%(\mathrm{v} / \mathrm{v})$ aliquots of the inoculum were transferred to
10 experimental Erlenmeyer flasks containing synthetic medium for the submerged fermentation experiment. The synthetic medium (the independent variable) contained: soybean oil (X1); corn oil (X2); glycerol (X3); glucose (X4); ammonium sulfate (X5); and yeast extract (X6). The exact concentrations of each were established by the factorial design determined using the Statistica 8.0 computer program (Table 2). After transferring the inoculum, the flasks were incubated at $25^{\circ} \mathrm{C}$ for $144 \mathrm{~h}$ while shaking at $200 \mathrm{rpm}$.

\section{Emulsifying index}

The emulsifying index was determined according Cooper and Goldenberg (1987) with slight modifications. The centrifuged fermented medium $(2 \mathrm{~mL})$ was transferred to test tubes and $2 \mathrm{~mL}$ of kerosene was added to it. The mixture was vortexed for $2 \mathrm{~min}$ and the tubes were left undisturbed for $24 \mathrm{~h}$. The percentage emulsifier index was calculated according to Equation 1:

Emulsifier index $(\%)=(H e x 100) / \mathrm{Ht}$

where,

$\mathrm{He}=$ emulsion height $(\mathrm{cm})$;

and, $\mathrm{Ht}=$ total height of the solution $(\mathrm{cm})$.

\section{Statistical analyses}

The experimental design and statistical analyses were evaluated using Statistica ${ }^{\circledR} 8.0$ (Weib, 2007).

\section{RESULTS AND DISCUSSION}

The coefficient of determination $\left(\mathrm{R}^{2}\right)$ of 0.999998 demonstrated an excellent relationship (99.99\%) between the experimental data and the curve established by the mathematical model. Therefore, only $0.01 \%$ of the variation in the emulsifying index could not be explained by the factors studied.

Table 1: Matrix of experimental design $2^{(6-2)}$ and the levels of the variables studied. Details of the 10 experiments chosen using the Statistica 8.0 computer program.

\begin{tabular}{|c|c|c|c|c|c|}
\hline \multirow{2}{*}{ Variables } & \multirow{2}{*}{ Unit } & \multirow{2}{*}{ Code } & \multicolumn{3}{|c|}{ Levels } \\
\hline & & & Minimum & Central & Maximum \\
\hline Soybean oil & $\mathrm{mL} 100 \mathrm{~mL}^{-1}$ & $\mathrm{X} 1$ & 2.0 & 11 & 20.0 \\
\hline Corn oil & $\mathrm{mL} 100 \mathrm{~mL}^{-1}$ & $\mathrm{X} 2$ & 2.0 & 11 & 20.0 \\
\hline Glycerol & $\mathrm{mL} 100 \mathrm{~mL}^{-1}$ & x3 & 2.0 & 11 & 20.0 \\
\hline Glucose & g $100 \mathrm{~mL}^{-1}$ & X4 & 1.0 & 5,5 & 10.0 \\
\hline Ammonium sulfate & g $100 \mathrm{~mL}^{-1}$ & X5 & 0.2 & 1.10 & 2.0 \\
\hline Yeast extract & g $100 \mathrm{~mL}^{-1}$ & $x 6$ & 0.2 & 1.10 & 2.0 \\
\hline
\end{tabular}


Using the experimental results, biosurfactant production was estimated from the emulsifying index in the fermented medium containing the three isolates (FS4.1; FS-4.2; FS-4.3) (Table 3).

Table 3 shows the emulsifying index values obtained for each isolate when grown under different experimental conditions. The emulsifying index of isolate FS-4.1 ranged from $6.06 \%$ to $73.45 \%$. The emulsifying index of isolate FS-4.2 ranged from $0.26-57.10 \%$. The emulsifying index of isolate FS-4.3 ranged from 7.30$68.82 \%$. The experimental conditions yielding the lowest emulsifying index for each isolate were: isolate FS-4.1, Experiment 08 (6.06\%); isolate FS-4.2, Experiment 05 $(0.26 \%)$; and isolate FS-4.3, Experiment 10 (7.18\%). The highest emulsifier index was obtained using isolate FS4.1 with Experiment 03 (73.45\%) (Table 3). Therefore, optimum growth conditions for producing biosurfactant were achieved using a medium consisting of $2 \%$ soybean oil, $20 \%$ corn oil, $2 \%$ glycerol, $1 \%$ glucose, $2 \%$ ammonium sulfate, and $0.2 \%$ yeast extract. In contrast, treatment with the maximum concentration (Experiment 08) presented an unfavorable condition for biosurfactant production, as evidenced by the low emulsifying index (6.06\%).

In Experiment 03, which yielded an emulsifier index of $73.45 \%$ for FS-4.1, corn oil and ammonium sulfate were the only components present at their maximum concentrations (Table 3 ). However, the second best emulsifier index (67.71\%) was obtained using

Table 2: Fractional factorial design $2^{(6-2)}$.

\begin{tabular}{ccccccc}
\hline Experiments & $\begin{array}{c}\text { Soybean oil } \\
(\mathrm{mL} / 100 \mathrm{~mL})\end{array}$ & $\begin{array}{c}\text { Corn oil } \\
(\mathrm{mL} / 100 \mathrm{~mL})\end{array}$ & $\begin{array}{c}\text { Glycerol } \\
(\mathrm{mL} / 100 \mathrm{~mL})\end{array}$ & $\begin{array}{c}\text { Glucose } \\
(\mathrm{g} / 100 \mathrm{~mL})\end{array}$ & $\begin{array}{c}\text { Ammonium sulfate } \\
(\mathrm{g} / 100 \mathrm{~mL})\end{array}$ & $\begin{array}{c}\text { Yeast extract } \\
(\mathrm{g} / 100 \mathrm{~mL})\end{array}$ \\
\hline 1 & 2.0 & 2.0 & 2.0 & 10.0 & 2.0 & 2.0 \\
2 & 2.0 & 2.0 & 20.0 & 10.0 & 0.20 & 0.20 \\
3 & 2.0 & 20.0 & 2.0 & 1.0 & 2.0 & 0.20 \\
4 & 2.0 & 20.0 & 20.0 & 1.0 & 0.20 & 2.0 \\
5 & 20.0 & 2.0 & 2.0 & 1.0 & 0.20 & 2.0 \\
6 & 20.0 & 2.0 & 20.0 & 1.0 & 2.00 & 0.20 \\
7 & 20.0 & 20.0 & 2.0 & 10.0 & 0.20 & 0.20 \\
8 & 20.0 & 20.0 & 20.0 & 10.0 & 2.0 & 2.0 \\
9 & 11.0 & 11.0 & 11.0 & 5.5 & 1.10 & 1.10 \\
10 & 11.0 & 11.0 & 11.0 & 5.5 & 1.10 & 1.10 \\
\hline
\end{tabular}

Table 3: Percentage emulsifying index of filamentous fungus species.

\begin{tabular}{crrrrlllrr}
\hline & \multicolumn{1}{c}{ Independent variables } & \multicolumn{4}{c}{ Emulsifying Index (\%) } \\
\hline Experiments & $\mathrm{X}_{1}$ & $\mathrm{X}_{2}$ & $\mathrm{X}_{3}$ & $\mathrm{X}_{4}$ & $\mathrm{X}_{5}$ & $\mathrm{X}_{6}$ & FS-4.1 & FS-4.2 & FS-4.3 \\
\hline 1 & 2 & 2 & 2 & 10 & 2 & 2 & 58.50 & 55.45 & 7.30 \\
2 & 2 & 2 & 20 & 10 & 0.2 & 0.2 & 67.71 & 6.94 & 36.69 \\
3 & 2 & 20 & 2 & 1 & 2 & 0.2 & 73.45 & 1.67 & 44.79 \\
4 & 2 & 20 & 20 & 1 & 0.2 & 2 & 11.25 & 10.33 & 56.25 \\
5 & 20 & 2 & 2 & 1 & 0.2 & 2 & 54.50 & 0.26 & 55.40 \\
6 & 20 & 2 & 20 & 1 & 2 & 0.2 & 59.76 & 1.83 & 45.03 \\
7 & 20 & 20 & 2 & 10 & 0.2 & 0.2 & 62.50 & 57.10 & 68.82 \\
8 & 20 & 20 & 20 & 10 & 2 & 2 & 6.06 & 29.34 & 10.97 \\
9 & 11 & 11 & 11 & 5.5 & 1.1 & 1,1 & 63.07 & 36.39 & 8.51 \\
10 & 11 & 11 & 11 & 5.5 & 1.1 & 1.1 & 63.55 & 26.02 & 7.18 \\
\hline
\end{tabular}

Source: Own. 
Experiment 2, with glycerol at $20 \%$ and glucose at $10 \%$, while the second worst emulsifier index $(11.25 \%)$ was obtained using Experiment 4, with corn oil and glycerol both at $20 \%$. The combination of soybean oil with corn oil or glycerol did not reduce the emulsifier index significantly (62.50 and 59.76, respectively). These results indicate that various combinations of culture medium components yield high values of emulsifier index.

The difference in emulsifier index values obtained between Experiment 3 and Experiment 8 (73.45\%$6.06 \%$ ) indicated that the emulsifying index increased by $67.39 \%$ when the concentration of these variables varied from their maximum level to their minimum level (while maintaining the concentration of the variables corn oil and ammonium sulfate at their maximum levels). Lack of adequate nutrients may limit high production of biosurfactant (Aguiar et al., 2015). However, the lower percentage of emulsification obtained in Experiment 8 may be related to excess of one or more components, or to the combination of different components at their maximum level.

For the isolates FS-4.2 and FS-4.3, the best results were obtained using Experiment 7, which yielded emulsifier indexes of $57.10 \%$ and $68.82 \%$, respectively. For the same Experiment, FS-4.1 showed an emulsifier index of $62.50 \%$, which was higher than the other isolates (although it was not the highest index). Therefore, we may conclude that the best Experiment for FS-4.1 was different from the best Experiment for FS-4.2 and FS-4.3. Likewise, the worst Experiment also differed for each isolate. It is worth noting that FS-4.1 showed an emulsifier index above $50 \%$ with eight Experiments, whereas for FS-4.2 and FS-4.3, an emulsifier index above $50 \%$ was obtained only with two and four Experiments, respectively. These results provide evidence of a higher potential for biosurfactant production from the isolate FS-4.1, which demonstrated high biosurfactant production in a wider range of cultivation media.

According to the statistical analyses, the independent variables and their interactions produced different positive and negative effects on the emulsifier index for the three isolates (Table 4).

Glycerol was the only independent variable to exert a negative effect on the emulsifier index for isolate FS$4.2(-16.5100)$. However, this effect was not statistically significant at the $95 \%$ confidence level $(p \geq 0.05)$. Although the interaction between soybean oil and yeast extract (X1 * X6) produced a negative effect $(-21.6250)$, this was not statistically significant ( $\mathrm{p} \geq 0.05$ ). Likewise, while the interaction between soybean oil, corn oil, and glucose $(\mathrm{X} 1 * \mathrm{X} 2 * \mathrm{X} 4)$ produced a negative effect $(-21.6800)$, this was not statistically significant at the $95 \%$ confidence level ( $\mathrm{p} \geq 0.05)$.

For isolate FS-4.3, the independent variables that had a negative effect on the emulsifier index were glycerol (-6.8401), glucose (-19.4228), ammonium sulfate $(-27.2671)$, and yeast extract $(-16.3544)$. The effects obtained with glucose, ammonium sulfate, and yeast extract were statistically significant at the $95 \%$ confidence level $(\mathrm{p} \leq 0.05)$. Although the interaction between soybean oil and yeast extract $(\mathrm{X} 1 * \mathrm{X} 6)$ produced a negative effect $(-7.3856)$, this was not statistically significant ( $\mathrm{p} \geq 0.05)$. In contrast, the interaction between the variables, soybean oil, corn oil, and glucose $(\mathrm{X} 1 * \mathrm{X} 2 * \mathrm{X} 4)$ produced a positive effect (65.6220), which was statistically significant at the $95 \%$ confidence level $(\mathrm{p} \leq 0.05)$.

Table 4: Estimates of the effects of each variable, their interactions, and significance $(p \leq 0.05)$ for the emulsifier index.

\begin{tabular}{cccc}
\hline & \multicolumn{3}{c}{ Estimates of the effects } \\
\hline Variables & FS-4.1 & FS-4.2 & FS-4.3 \\
\hline Soybean oil $\left(X_{1}\right)$ & $-7.0218^{*}$ & 3.5350 & $8.7956^{*}$ \\
Corn oil $\left(X_{2}\right)$ & $-21.8023^{*}$ & 8.4900 & $9.1023^{*}$ \\
Glycerol $\left(X_{3}\right)$ & $-26.0448^{*}$ & -16.5100 & -6.8401 \\
Glucose $\left(X_{4}\right)$ & -1.0492 & 33.6850 & $-19.4228^{*}$ \\
Ammonium sulfate $\left(X_{5}\right)$ & 0.4533 & 3.4150 & $-27.2671^{*}$ \\
Yeast extract $\left(X_{6}\right)$ & $-33.2769^{*}$ & 6.9600 & $-16.3544^{*}$ \\
$X_{1 *} X_{6}$ & 2.4290 & -21.6250 & -7.3856 \\
$X_{1}^{*} X_{2}{ }^{*} X_{4}$ & $-28.1847^{*}$ & -21.6800 & $65.6220^{*}$ \\
\hline
\end{tabular}

*indicates statistical significance at the $95 \%$ confidence level $(p \leq 0.05)$. 
Accorsini et al. (2012) studied the production of biosurfactants by yeast and found that soybean oil and glucose are excellent carbon sources for biosurfactant production. The emulsifying indices obtained in this work corroborated the findings of the earlier studies which reported emulsifying indices between 49-64.3\% (Dikit et al., 2010), 53.0\% (Luz et al., 2011), 62.5\% \pm 0.88 (Decesaro et al., 2013), 61.00\% (Santos; Linard, 2004), and 48.89\% (Mollea; Bosco; Ruggeri, 2005).

Figures 1, 2, and 3 show Pareto graphs of the significant effects $(\mathrm{p} \leq 0.05)$ of isolates FS-4.1, FS-4.2, and FS-4.3, respectively. All values to the right of the dashed line are statistically significant $(\mathrm{p} \leq 0.05)$. Analyzing the Pareto graph of isolate FS-4.1 (Figure 1), we observed that yeast extract exerted the most negative effect, while glucose exerted the least relevant negative effect on biosurfactant production. On the contrary, the most significant positive effect on biosurfactant production was caused by the interaction between soybean oil and yeast extract $(\mathrm{X} 1 * \mathrm{X} 6)$, while ammonium sulfate had the least positive effect.

Analyzing the Pareto graph of isolate FS-4.2 (Figure 2), we observed that glucose had the most positive effect on biosurfactant production, while ammonium sulfate had the least positive effect. The interaction between soybean oil and yeast extract $(\mathrm{X} 1 * \mathrm{X} 6)$ had the most negative effect on biosurfactant production, while the interaction between soybean oil, corn oil, and glucose $(\mathrm{X} 1 * \mathrm{X} 2 * \mathrm{X} 4)$ had the least relevant negative effect.

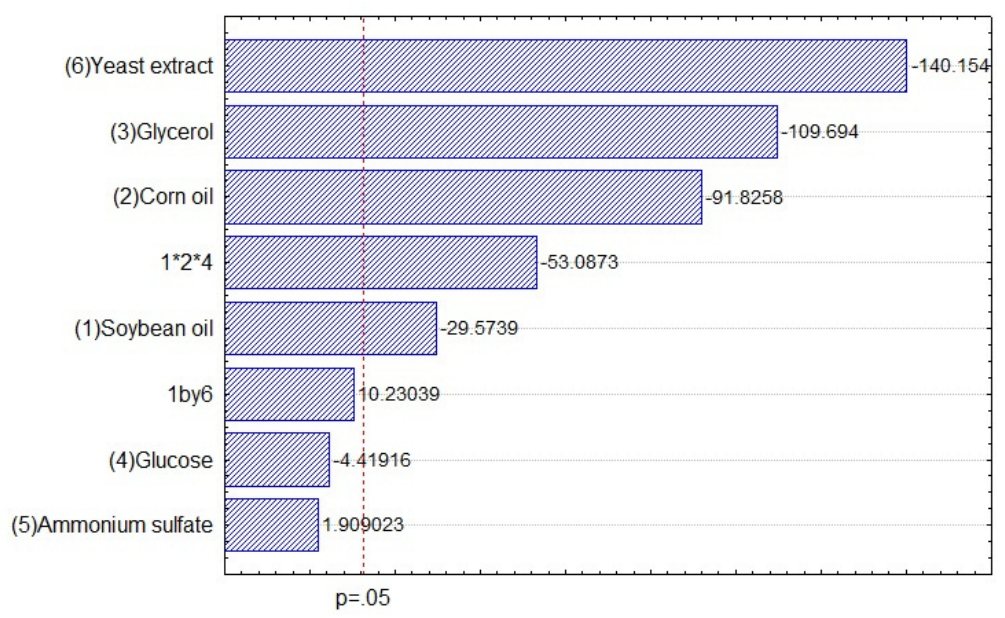

Figure 1: Pareto graph of isolate FS-4.1 with standardized absolute values of the effects of each variable and their interactions.

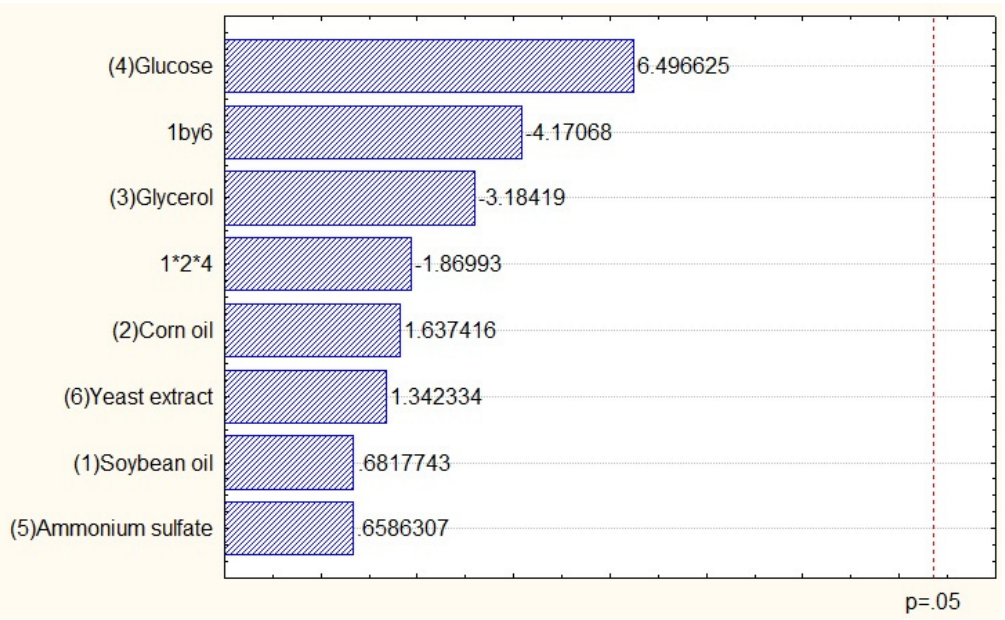

Figure 2: Pareto graph of isolate FS-4.2 with standardized absolute values of the effects of each variable and their interactions. 


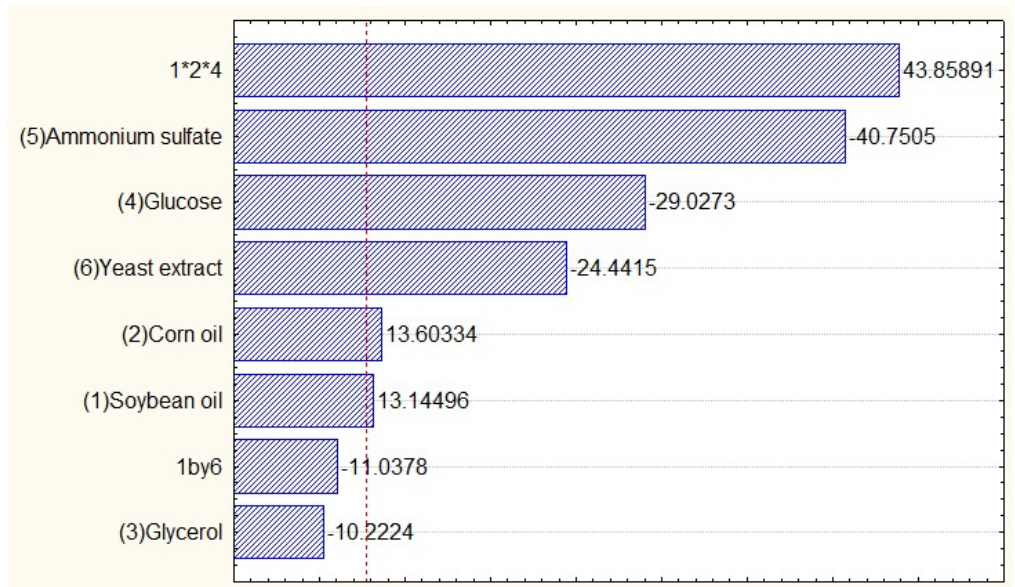

Figure 3: Pareto graph of isolate FS-4.3 with standardized absolute values of the effects of each variable and their interactions.

According to the Pareto graph of isolate FS-4.2 (Figure 3), the interaction between soybean oil, corn oil, and glucose $(\mathrm{X} 1 * \mathrm{X} 2 * \mathrm{X} 4)$ had the most positive effect on biosurfactant production, while soybean oil had the least positive effect. Ammonium sulfate had the most negative effect on biosurfactant production, and glycerol had the least relevant negative effect.

Microbial production of biosurfactants may be achieved using different substrates, but the composition and characteristics of the biosurfactants are influenced by the nature of the carbon and nitrogen sources used (Fontes et al., 2008). Therefore, a study of the nutritional requirements and process conditions of microbial production is essential. Decesaro et al. (2013) studied the production of biosurfactants using microorganisms isolated from diesel oil-contaminated soil as a function of nitrogen source and inducer type (soybean oil and diesel oil). The best results were obtained using $1 \%$ soybean oil as an inducer, without the addition of ammonium sulfate as a nitrogen source. Considering the results shown in Figure 4, it can be inferred that within the range of conditions studied for isolate FS-4.1, nitrogen source influences the emulsifier index.

Yeast extract exerted a negative influence on biosurfactant production, with a statistical significance at the $95 \%$ confidence level $(p \leq 0.05)$. In contrast, ammonium sulfate exerted a positive influence on biosurfactant production, although this effect was not statistically significant ( $\mathrm{p} \geq 0.05$ ).

In addition, the different carbon sources also influenced the emulsifier index of isolate FS-4.1 (Figure 5). Although glucose had a negative influence on biosurfactant production, the effect was not statistically significant at the $95 \%$ confidence level ( $p \geq 0.05$ ). The combination of water-insoluble substrate (soybean oil) and carbohydrate (glucose) also increased biosurfactant production by isolate FS-4.1. However, glycerol demonstrated a statistically significant negative influence $(p \leq 0.05)$ on biosurfactant production as shown in Figure 5 (a). As the glycerol concentration increased (X3) and glucose concentration (X4) decreased, the emulsifier index decreased. In contrast, the emulsifier index increased when the glycerol concentration decreased (X3) and glucose concentration (X4) increased.

Several studies have reported the production of biosurfactants as a function of the composition of the culture medium, type of microorganism, and process operational conditions (Barth; Gaillardin, 1997; Casas; Ochoa, 1999; Amezcuavega et al., 2007; Fontes et al., 2008; Luna; Sarubbo; Campos-Takaki, 2009; Das; Kumar, 2019). According to Napp et al. (2018), several microorganisms can degrade or assimilate hydrocarbons. Among these microorganisms, many are capable of emulsifying these hydrocarbons during substrate degradation.

Biosurfactant production can be spontaneous or it can be induced by the presence of lipophilic compounds, by variations in $\mathrm{pH}$, temperature, aeration, and agitation speed, or by cell growth under stress conditions, such as low nitrogen concentrations (Desai; Banat, 1997). Many additional factors influencing the production of biosurfactants have been explored in previous studies, including the effects of sugars, glycerol, ethanol, 
crude oil, alkanes, paraffin, vegetal oils, and agroindustrial waste on different types of substrates (Barth; Gaillardin, 1997; Desai; Banat, 1997; Casas; Ochoa, 1999; Ravelet et al., 2000; Lukondeh; Ashbolt; Rogers, 2003; Amezcuavega et al., 2007; Luna et al., 2009; Decesaro et al., 2013). In addition to the effects of the type of substrate, nutrient availability, carbon source, environmental conditions, and other factors, production efficiency is also determined by the genetics of the microorganisms (Lukondeh; Ashbolt; Rogers, 2003). In the present study, large differences in biosurfactant production were observed between different isolates, providing evidence of a significant role played by the genetic difference between the isolates.

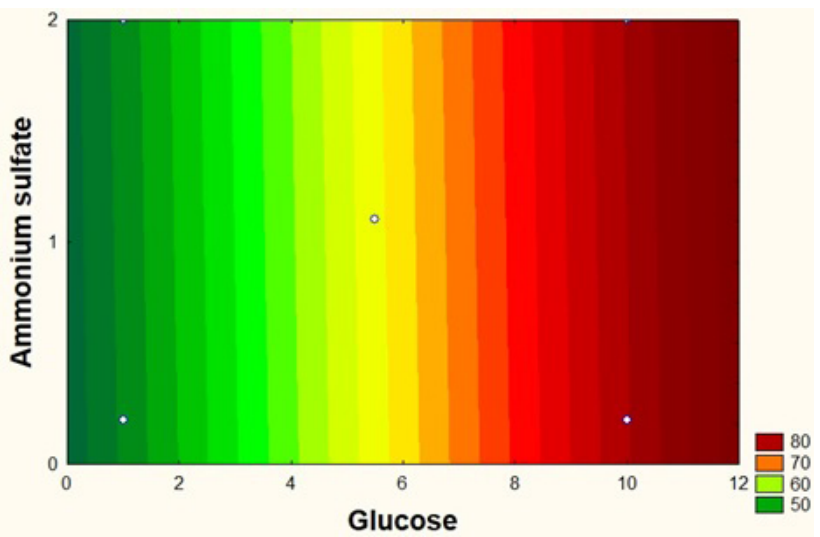

Figure 4: Contour graphs showing the effects of the independent variables on the emulsifier index of isolate FS4.1. Source: Statistica 8.0 computer program.
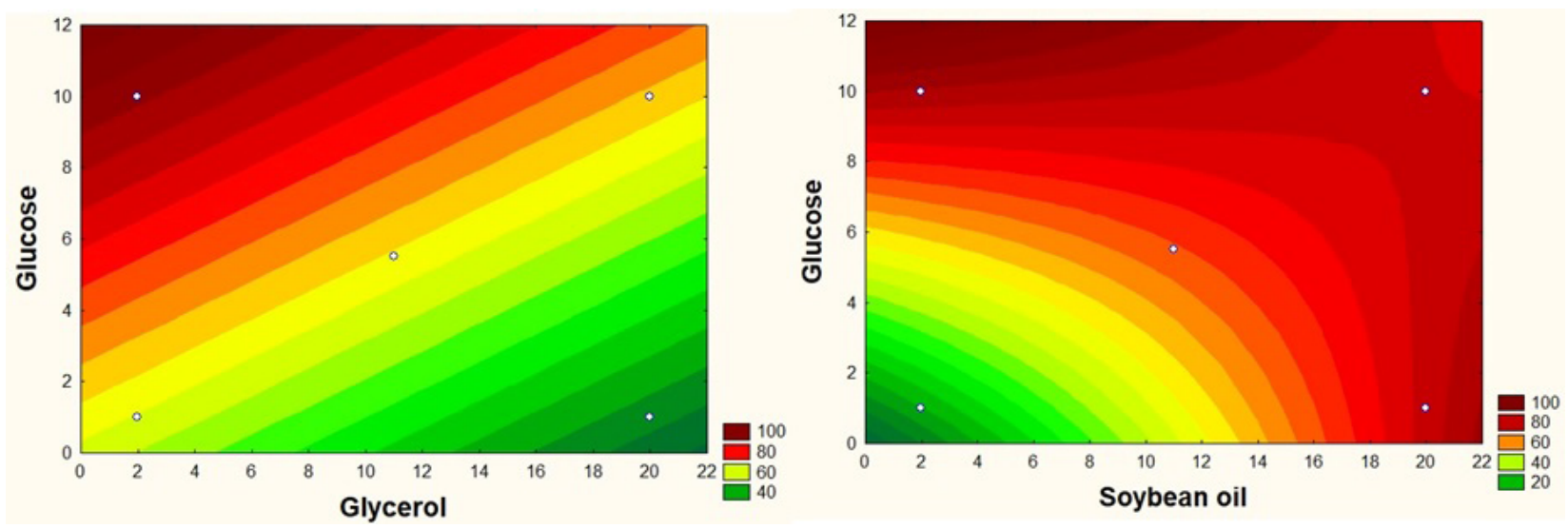

Figure 5: Contour graphs showing the effects of independent variables on the emulsifier index of isolate FS-4.1. Source: Statistica 8.0 computer program. 


\section{CONCLUSIONS}

It is reported on a new group of basidiomycetes capable of producing biosurfactants. Coprinaceous fungi demonstrate great potential as biosurfactant producers. While all three isolates investigated in the present study demonstrated biosurfactant production capabilities, biosurfactant production by isolate FS-4.1 subjected to Experiment 03 was most notable, yielding an emulsifying index of $73.45 \%$. To maximize the biosurfactant production, it was necessary to adjust the concentration of culture medium components (to eliminate any negative effects on the process) and increase the amounts of glucose and soy oil. Our results can be used to design improved production processes by considering the parameters that positively influenced biosurfactant production.

\section{ACKNOWLEDGMENTS}

The FAPEMIG (Fundação de Amparo à Pesquisado Estado de Minas Gerais), CAPES (Coordenação de Aperfeiçoamento de Pessoal de Nível Superior) and CNPq (Conselho Nacional de Desenvolvimento Científico e Tecnológico) are acknowledged for financial support. We would like to thank Editage (www.editage.com) for English language editing.

\section{REFERENCES}

ACCORSINI, F. R. et al. Biosurfactants production by yeasts using soybean oil and glycerol as low cost substrate. Brazilian Journal of Microbiology, 43(1):116-125, 2012.

AGUIAR, G. P. S. et al. Influência do meio mineral na produção de biossurfactantes. Revista de Engenharia e Tecnologia, 7(1):115-119, 2015.

AMEZCUAVEGA, C. et al. Effect of culture conditions on fatty acids composition of a biosurfactant produced by Candida Ingens and changes of surface tension of culture media. Bioresource Technology, 98(1):237-240, 2007.

ASGHER, M. et al. Improved biosurfactant production from Aspergillus niger through chemical mutagenesis: Characterization and RSM optimization. SN Applied Sciences, 2:e966, 2020.

BANAT, I. Biosurfactants production and possible uses in microbial enhanced oil recovery and oil pollution remediation: A review. Bioresource Technology, 51(1):1-12, 1995.

BARTH, G.; GAILLARDIN, C. Physiology and genetics of the dimorphic fungus Yarrowia Lipolytica. FEMS Microbiology Reviews, 19(4):219-237, 1997.
CASAS, J. A.; OCHOA, F. G. Sophorolipid production by Candida Bombicola: Medium composition and culture methods. Journal of Bioscience and Bioengineering, 88(5):488494, 1999.

COOPER, D. G.; GOLDENBERG, B. G. Surface-active agents from two Bacillus species. Applied and Environmental Microbiology, 53(2):224-229, 1987.

DAS, A. J.; KUMAR, R. Production of biosurfactant from agroindustrial waste by Bacillus Safensis $\mathrm{J} 2$ and exploring its oil recovery efficiency and role in restoration of diesel contaminated soil. Environmental Technology and Innovation, 16:e100450, 2019.

DA SILVA, M. E. et al. Biosurfactant production of Piper hispidum endophytic fungi. Journal of Applied Microbiology, 127:19, 2019.

DECESARO, A. et al. Produção de biossurfactantes por microrganismos isolados de solo contaminado com óleo diesel. Quimica Nova, 36 (7):947-954, 2013.

DESAI, J. D.; BANAT, I. M. Microbial production of surfactants and their commercial potential. Microbiology and Molecular Biology Reviews, 61(1):47-64, 1997.

DIKIT, P. et al. Emulsifier properties of the mannoprotein extract from yeast isolated from sugar palm wine. Science Asia, 36:312-318, 2010.

EGGEN, T.; SASEK, V. Use of edible and medicinal oyster mushroom Pleurotus ostreatus (Jacq.: Fr.) kumm. Spent compost in remediation of chemically polluted soils. International Journal of Medicinal Mushrooms, 4(3):255261, 2002.

FONTES, G. C. et al. Produção de biossurfactante por levedura. Quimica Nova, 31(8):2091-2099, 2008.

JOSHI, S. et al. Production of biosurfactant and antifungal compound by fermented food isolate Bacillus subtilis 20B. Bioresource Technology, 99(11):4603-4608, 2008.

KARLAPUDI, A. P. et al. Role of biosurfactants in bioremediation of oil pollution-a review. Petroleum, 4(3):241-249, 2018.

$\mathrm{KHOPADE}$, A. et al. Production and stability studies of the biosurfactant isolated from marine Nocardiopsis sp. B4. Desalination, 285:198-204, 2012.

LARGENT, D. L.; SUNTZ, D. E.; HADLEY, S. How to identify mushrooms to genus III: Microscopic features. Mad River, third ed. California, 1986. 166p. 
LIN, Y.; GE, X.; LI, Y. Solid-state anaerobic co-digestion of spent mushroom substrate with yard trimmings and wheat straw for biogas production. Bioresource Technology, 169:468-474, 2014.

LUKONDEH, T.; ASHBOLT, N. J.; ROGERS, P. L. Evaluation of Kluyveromyces marxianus FII 510700 grown on a lactosebased medium as a source of a natural bioemulsifier. Journal of Industrial Microbiology and Biotechnology, 30(12): 715-720, 2003.

LUNA, J. M. de.; SARUBBO, L.; CAMPOS-TAKAKI, G. M de. A new biosurfactant produced by Candida Glabrata UCP 1002: Characteristics of stability and application in oil recovery. Brazilian Archives of Biology and Technology, 52(4):785793, 2009.

LUZ, C. C. et al. Estudos de biodegradação de óleo diesel por consórcio microbiano coletado em Porto Velho - RO, Amazônia. Química Nova, 34(5):775-779, 2011.

MOLLEA, C.; BOSCO, F.; RUGGERI, B. Fungal biodegradation of naphthalene: Microcosms studies. Chemosphere, 60(5):636-643, 2005.

MONTGOMERY, D. C. Design and analysis of experiments. 3rd Edition. United States: John Wiley \& Sons. 1991. 576p.

MORAES, T. S. J. et al. Fungal and bacterial population from spent mushroom substrate used to cultivate tomato plants. Ciência e Agrotecnologia, 44:e010120, 2020.

MUKHERJEE, S.; DAS, P.; SEN, R. Towards commercial production of microbial surfactants. Trends in Biotechnology, 24(6):509-515, 2006.

NAPP, A. P. et al. Comparative metagenomics reveals different hydrocarbon degradative abilities from enriched oil-drilling waste. Chemosphere, 209:7-16, 2018.

PERALTA-ZAMORA, P.; MORAES, J. L. de.; NAGATA, N. Por que a otimização variada? Engenharia Sanitária e Ambiental, 10(2):106-110, 2005.

PEREIRA, D. D. F.; DUVOISIN, J. R. S.; ALBUQUERQUE, P. M. $O$ estudo da produção de biossurfactantes por fungos amazônicos. The Journal of Engineering and Exact Sciences, 3(4):688-695, 2017.

PEREIRA-FILHO, E. R.; POPPI, R. J.; ARRUDA, M. A. Z. Emprego de planejamento fatorial para a otimização das temperaturas de pirólise e atomização de Al, Cd, Mo e Pb por ETAAS. Química Nova, 25(2):246-253, 2002.

PUTZKE, J.; PUTZKE, M. T. L. Cogumelos - Fungos agaricales no Brasil, familias agaricaceae, amanitaceae, bolbitaceae, entolomataceae, coprinaceae/ psathyrellaceae, crepidotaceae e hygrophoraceae. vol. 1. São Gabriel: Editora JP, 2017. 521p.

RANI, M.; WEADGE, J. T.; JABAJI, S. Isolation and characterization of biosurfactant-producing bacteria from oil well batteries with antimicrobial activities against food-borne and plant pathogens. Frontiers in Microbiology, 11:64, 2020.

RAVELET, C. et al. Biodegradation of pyrene by sediment fungi. Chemosphere, 40(5):557-563, 2000.

RINKER, D. L. Spent mushroom substrate uses: Technology and applications. Edible and medicinal mushrooms: Technology and applications (First edit), John Wiley \& Sons Ltda. p.427-454. 2017.

SANCHES, M. A. et al. Biosurfactant production by Fusarium oxysporum LM 5634 using peels from the fruit of Bactris gasipaes (Kunth) as substrate. Biotechnology Journal International, 21(1):1-9, 2018.

SANTOS, V. L.; LINARD, V. R. Biodegradation of phenol by a filamentous fungi isolated from industrial effluents - Identification and degradation potential. Process Biochemistry, 39(8):1001-1006, 2004.

SEN, S. et al. Production, characterization, and antifungal activity of a biosurfactant produced by Rhodotorula babjevae YS3. Microbial Cell Factory, 16:95-109, 2017.

SOARES, I. A. et al. Fungos na biorremediação de áreas degradadas. Arquivos do Instituto Biológico,78(2):341-350, 2011.

WEIB, C. H. StatSoft, Inc., Tulsa, OK.: STATISTICA, Version 8. AStA Advances in Statistical Analysis, 91(3):339-341, 2007.

VAN DEN BRINK, H. J. M. et al. Cytochrome P450 enzyme systems in fungi. Fungal Genetics and Biology, 23(1):1$17,1998$.

VAN HAMME, J. D.; SINGH, A.; WARD, O. P. Physiological aspects: Part 1 in a series of papers devoted to surfactants in microbiology and biotechnology. Biotechnology Advances, 24(6):604-620, 2006.

VARJANI, S. J.; UPASANI, V. N. A new look on factors affecting microbial degradation of petroleum hydrocarbon pollutants. International Biodeterioration and Biodegradation, 120:71-83, 2017.

ZHAO, F. et al. Biosurfactant production under diverse conditions by two kinds of biosurfactant-producing bacteria for microbial enhanced oil recovery. Journal of Petroleum Science and Engineering, 157:124-130, 2017. 